International Journal of

Advanced Science and Convergence

\title{
Interactive 3D Directory: University of La Salette
}

\author{
Dreivan B. Orprecio ${ }^{1}$, Harvie A. Bañares ${ }^{1}$, Lary Jay C. Guzman ${ }^{1}$, Jielie C. Conjusta ${ }^{1}$ \\ and Genesis S. Jose ${ }^{1}$ \\ ${ }^{1}$ College of Engineering, University of La Salette, Santiago City, Isabela, 3311, Philippines
}

\begin{abstract}
Background/Objectives: There is an impact of multimedia on engineering students. They use interactive multimedia to simulate scenarios in computer applications, electronics, and later implement and calibrate their designs in an actual environment. Architecture students use interactive multimedia for design presentations. Methods/Statistical analysis: This study focuses on the development of the Interactive 3D Directory for the University of La Salette. As Computer Engineers, we want to showcase our skills and knowledge to the locality and to help the end-users, i.e., visitors, new students, and transferees, to locate buildings and departments in this University. We used Unity3d, c\# programming, and SketchUp to develop this project. This study used the survey method to acquire related data. Questionnaires were floated before and after the implementation of the system. Findings: The results found out that most of the time, new students, transferees, visitors ask directions and feel the need for a system that gives accurate directions. The results also found out that most of the respondents agree that the developed system was effective and easy to use. Improvements/Applications: Based on the study findings, the researchers suggest that the administration introduce the established program on all of the region's high school campuses to help visitors, transferees, and new students identify offices, facilities, and departments.
\end{abstract}

\section{Index Terms}

3-Dimensional, Interactive, Visualization, Map, Directory

\footnotetext{
Corresponding author : G. S. Jose

josegenesis007@gmail.com

- Manuscript received April 17, 2020.

- Revised May 22, 2020 ; Accepted June 20, 2020.

- Date of publication June 30, 2020.

(C) The Academic Society of Convergence Science Inc.

2619-8150 @ 2019 IJASC. Personal use is permitted, but republication/redistribution requires IJASC permission.
} 


\section{INTRODUCTION}

Traditional maps displaying the geographic objects in 2D have been used thousands of years. Human beings had been not realized their dream of displaying the real world as it is in 3D and more until the invention of the computer. [1]

The creation of 3D visualizations has mostly been driven by rapidly developing technology rather than cognitive and perceptual theories and/or user-centered thinking $[2,3]$. As the processing power and memory capacity of computers increased and software became more sophisticated, the use of 3D graphics in many domains increased-simply because it was now possible to create them. Therefore, the use of 3D visualization seems to be prevalent today, but there is very little comprehension or knowledge if $3 \mathrm{D}$ visualizations work as intended for the target audiences and tasks. [4]

Information and Computer scientists have established a foundation of analysis and computer graphics techniques that can be used to visualize geographic entities, landscapes, and geographic information System GIS data layers. These techniques have undergone a radical transformation due to rapid advances in Computer hardware and software and geographic information technology (GIT). [5]

The use of the Internet achieves the interactive application of 3D maps. The entire process of gathering information and sources and their processing is shown. For this aim, the satellite images are imported in the AutoCAD environment. After that, the sources are scaled and vectorized to be prepared for the 3D platform. Technology is upgraded in the steps of defining virtual cameras and spotlights as well in the process of creating maps for touristic usage. Moreover, the Internet application with interactive possibilities for user manipulation is created, and all steps are proposed. [6]

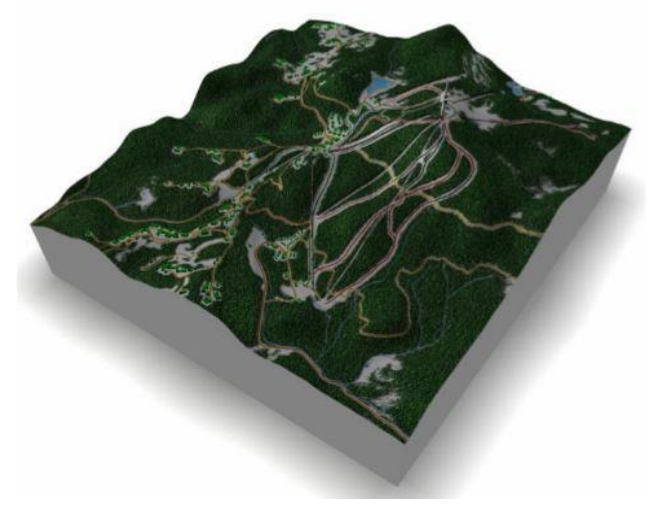

Fig. 13 D map for internet application
Complex 3D virtual representations of walls and floors indoor spaces to objects and their configurations can provide extensive knowledge about the environments as well as rich contextual Data about people living there and how they communicate with the environment. When cameras are omnipresent and rapidly growing use, detailed 3D visual models will be the foundation for future context-aware applications. [7]

Virtual reality technology is an emerging technology and is widely used. Virtual campus can actually show the interactive $3 \mathrm{D}$ campus scene, there is no time and space restriction. Using the Chaoyang District of Jilin University as an example, introduce methods for setting up a virtual campus based on 3D modeling, image processing and database technology. SketchUp is used to make a 3D model. [8]

This study focuses on the development of the Interactive 3D Directory for the University of La Salette using a game engine and Sketchup to create a virtual environment (VEs).

The Unity Game Engine was designed by Unity Technologies in Demark. Unity integrates a custom rendering engine with the Nvidia PhysX physics engine and Mono, the open implementation of Microsoft. NET libraries. [9] Unity is a multi-platform game engine for creating interactive 3D content. It includes an intuitive interface while at the same time providing low-level access for developers. [10]

\section{Methodology}

\section{A. Research Design}

This study used a survey method in data collection. Surveys, as per Pinsonneault and Kraemer (1993), are the methods for "gathering information about Attributes, acts, or views of a wide group of individuals." The mode of data collection was a selfadministered questionnaire. Questionnaires were floated before and after the implementation of the system.

\section{B. Study Site and Participants}

The study was conducted at the University of La Salette, Santiago City, Isabela. The University of La Salette is the only university founded by the missionaries of Our Lady of La Salette, France. The University has a land area of 66,877.44 sq. meters with different structures buildings for tertiary and secondary levels, dormitories, hospitals, Gymnasiums, open fields for outdoor activities, canteens, and parking lots. The participants of the study were 23 visitors, 12 transferees, and 66 new students, a total of 101 participants. 


\section{Research Techniques}

This study used a five-point Likert scale devised by Rensis Likert (1932). The five-point Likert scale used in this study employs the following $(5=$ strongly Agree; Always, 4= Agree; Most of the time, $3=$ Moderately Agree; Sometimes, 2 = Disagree; Rarely, $1=$ Strong disagree; never). The percent was also used in the demographic profile of the participants.

\section{Data Collection Procedure}

After securing permission from the Administrators of the University of La Salette to conduct the study, the researchers gathered necessary data from people who have broad knowledge in this field; previous research papers; related journals; maps; articles on the internet; and any other possible useful resources they might encounter during the process.

The researchers identified possible participants in the study and explained the purpose of the study. The selected participants were given a copy of the first set of self-administered questionnaires to find out the current situations and problems.

The results of the questionnaires were tallied and used as a basis in the development of the system.

The researchers implement the system for one month and continuously monitor the behavior of the system for calibration and upgrades.

After the implementation phase, the researchers presented the developed system to the participants and gave the second set of self-administered questionnaires for them to evaluate the system.

The results of the questionnaires were tabulated and interpreted.

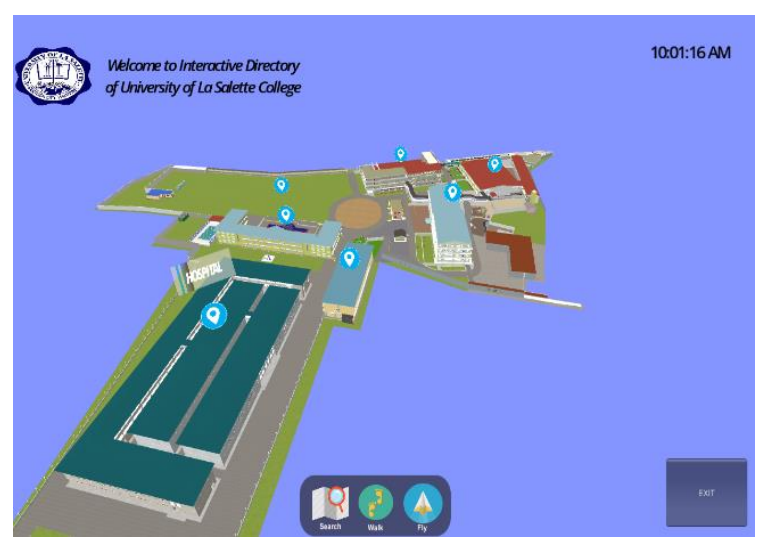

Fig. 2 Preview Screen of the Developed System

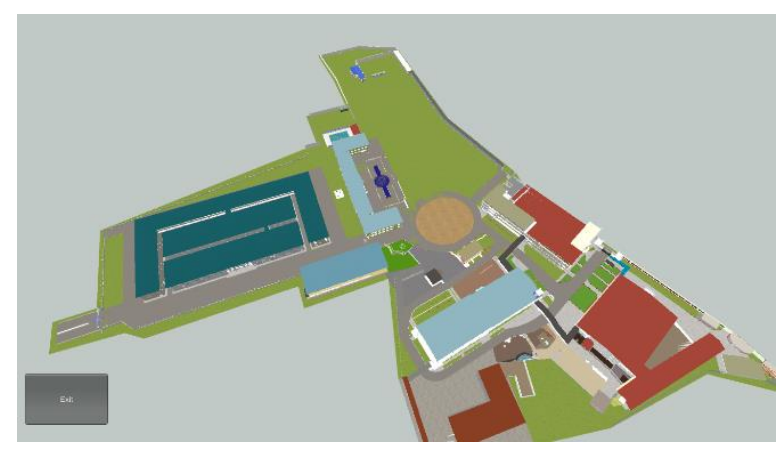

Fig. 3 Flythrough Feature of the Developed System

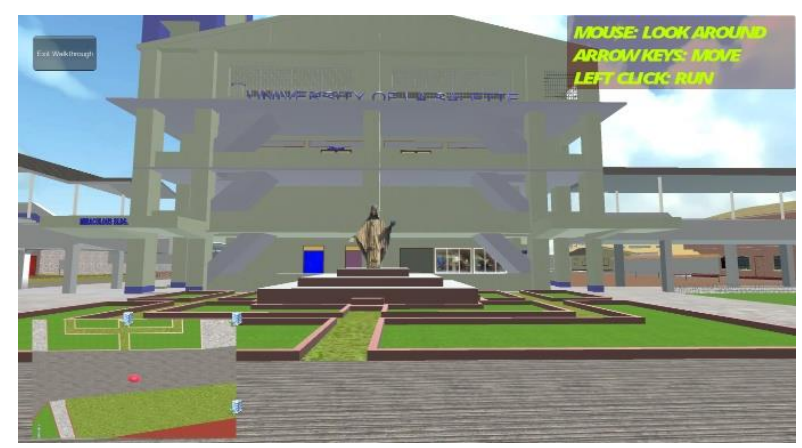

Fig. 4 Walkthrough Feature of the Developed System

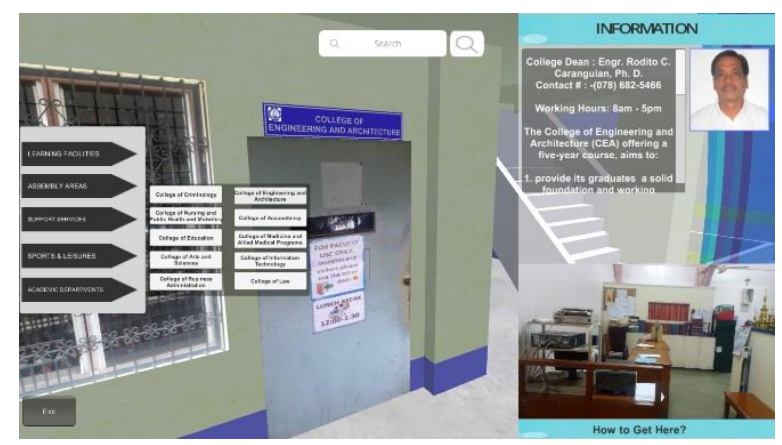

Fig. 5 Office Profile of the Developed System

\section{Data Presentation}

\section{A. Results of the Surveys}

Self-administered questionnaires were used to gather data needed in the development of the 3D Interactive Directory.

The first set of questionnaires was dedicated to new students, visitors, and transferees to determine the current situations, problems, and if there is a need for this kind of system. 
Table 1. VISITORS AND NEW STUDENTS' EXPERIENCES IN LOCATING BUILDINGS AND OFFICES $(\mathrm{N}=101)$

\begin{tabular}{|l|c|c|}
\hline \multicolumn{1}{|c|}{ Questions } & Mean & $\begin{array}{c}\text { Verbal } \\
\text { Interpretati } \\
\text { on }\end{array}$ \\
\hline $\begin{array}{l}\text { How often visitors, new } \\
\text { students, and transferees } \\
\text { ask for directions? }\end{array}$ & 3.72 & $\begin{array}{c}\text { Most of the } \\
\text { time }\end{array}$ \\
\hline $\begin{array}{l}\text { Giving directions around } \\
\text { the campus to visitors, } \\
\text { new students, and } \\
\text { transferees are hard. }\end{array}$ & 3.72 & $\begin{array}{c}\text { Most of the } \\
\text { time }\end{array}$ \\
\hline $\begin{array}{l}\text { I can always give an } \\
\text { accurate direction to } \\
\text { visitors, new students, } \\
\text { and transferees. }\end{array}$ & 3.42 & \begin{tabular}{c} 
Sometimes \\
\hline $\begin{array}{l}\text { I am familiar with all the } \\
\text { different offices and } \\
\text { facilities inside the } \\
\text { campus. }\end{array}$
\end{tabular} \\
\hline $\begin{array}{l}\text { I feel the need to have a } \\
\text { 3D map. }\end{array}$ & 2.87 & Moderately \\
\hline $\begin{array}{l}\text { I think it will be much } \\
\text { easier to give directions } \\
\text { to visitors and new } \\
\text { students if there is a 3D } \\
\text { map available. }\end{array}$ & 4.59 & Agree \\
\hline
\end{tabular}

Table 1 shows that visitors, new students, and transferees often ask directions. Students find it hard to give directions accurately to the visitors, new students, and transferees. Based on the result, the students were not familiar with different offices and facilities on the campus. The students feel the need for a 3D map to give directions to visitors, new students, and transferees.

The second set of questionnaires is given to the same respondents for system evaluation.

Table 2. User's EVAluATION OF THE SYSTEM (N=101)

\begin{tabular}{|l|c|c|}
\hline \multicolumn{1}{|c|}{ Criteria } & Mean & $\begin{array}{c}\text { Verbal } \\
\text { Interpretation }\end{array}$ \\
\hline $\begin{array}{l}\text { The correctness of the } \\
\text { orientation } \\
\text { The virtual path given } \\
\text { by system corresponds } \\
\text { with the real } \\
\text { environment }\end{array}$ & 4.49 & Agree \\
\hline $\begin{array}{l}\text { The fastness of the } \\
\text { search function } \\
\text { I have found the target } \\
\text { location within 5 } \\
\text { seconds }\end{array}$ & 4.19 & Agree \\
\hline $\begin{array}{l}\text { The efficiency of the } \\
\text { selected route }\end{array}$ & 4.52 & Strongly Agree \\
\hline
\end{tabular}

\begin{tabular}{|l|l|l|}
\hline $\begin{array}{l}\text { The system gave the } \\
\text { desired path of an } \\
\text { office or room }\end{array}$ & & \\
\hline $\begin{array}{l}\text { The satisfaction of the } \\
\text { system }\end{array}$ & 4.56 & Strongly Agree \\
$\begin{array}{l}\text { I find the Interactive 3D } \\
\text { pathfinding useful in } \\
\text { getting directions }\end{array}$ & & \\
\hline
\end{tabular}

Table 2 shows the system evaluation of the Interactive 3D Directory for the University of La Salette. The correctness of the orientation and Fastness of the search function got a mean of 4.49 and 4.19 , respectively. The efficiency of the selected route and Satisfaction of the system got a weighted way of 4.52 and 4.56 , respectively.

\section{Conclusion}

The study focused on the development of an interactive 3D directory for the University of $\mathrm{La}$ Salette that will help new students, transferees, and visitors in locating offices, departments, and other facilities. The researchers found out that new students, transferees, and visitors were troubled in visualizing and familiarizing their new environment and feel the need for a system that will enable them to familiarize their new environment on their own. A developed system by the researchers was implemented and satisfied with the clients of the University. The researchers recommended to the administration the implementation of the developed system to all its high school campuses in the region.

\section{REFERENCES}

[1] Chen, X., \& Bai, F. (2001). Generalization of threedimensional city maps. In Proceedings of the 20th International Cartographic Conference 3, 2083-2090.

[2] Coltekin, A., \& Haggrén, H. (2000). VRML as a Tool for WEB-based, 3D, Photo-realistic GIS. International Archives of Photogrammetry and Remote Sensing 33(B5/1; Part 5), 143-148.

[3] Fuhrmann, S., Ahonen-Rainio, P., Edsall, R. M., Fabrikant, S. I., Koua, E., Tobón, L., Ware, C., \& Wilson, S. (2005). Making useful and useable geovisualization: design and evaluation issues. International Cartographic Association, 551-566. https://doi.org/10.1016/B978-008044531-1/50446-2

[4] Çöltekin, A., Lokka, I. E., Zahner, M., \& Halounova, L. (2016). On the usability and usefulness of 3D (geo) visualizations--A focus on virtual reality environments. XXIII ISPRS Congress, 387-392, Commission II, Prague, July 12, 2016 - July 19, 2016.

[5] Buckley, A., Hurni, L., Kriz, K., Patterson, T., \& Olsenholler, J. (2004). Cartography and visualization 
in mountain geomorphology. In M. P. Bishop and J. F. Shroder, Jr. (Eds.), Geographic Information Science and Mountain Geomorphology, 253-287.UK, Springer.

[6] Bandrova, T., \& Bonchev, S. (2010). 3D maps for internet application. 3rd ISDE Digital Earth Summit, Nessebar, Bulgaria, 12-14.

[7] Du, H., Henry, P., Ren, X., Cheng, M., Goldman, D. B., Seitz, S. M., \& Fox, D. (2011). Interactive 3D modeling of indoor environments with a consumer depth camera. In Proceedings of the 13th International Conference on Ubiquitous computing, 75-84. Beijing, China, September 17 - 21, 2011.

https://doi.org/10.1145/2030112.2030123

[8] Hong, D. F., Yang, G. D., \& Wang, Z. H. (2008). Construction of Virtual Campus Based on ArcScene and SketchUp [J]. Computer Technology and Development, 12, 014.

[9] Craighead, J., Burke, J., \& Murphy, R. (September 2008). Using the unity game engine to develop sarge: a case study. In Proceedings of the 2008 Simulation Workshop at the International Conference on Intelligent Robots and Systems (IROS 2008).

[10] J. Jerald, P. Giokaris, D. Woodall, A. Hartbolt, A. Chandak and S. Kuntz(2014). Developing virtual reality applications with Unity, 2014 IEEE Virtual Reality (VR), Minneapolis, MN, 2014, pp. 1-3. DOI : 10.1109/VR.2014.6802117 